\title{
Street-level bureaucracy and policy implementation in community public health nursing: a qualitative study of the experiences of student and novice health visitors
}

\author{
Alison Hughes ${ }^{1}$ and Louise Condon ${ }^{2}$ \\ ${ }^{1}$ Senior Lecturer, Department of Nursing and Midwifery, University of the West of England, Bristol, UK \\ ${ }^{2}$ Associate Professor, College of Human and Health Sciences, Swansea University, Swansea, UK
}

\begin{abstract}
Aim: To explore the experiences of student and novice health visitors in implementing health visiting policy reform pre- and post-qualification. Background: In England, public health nursing has been subject to major policy reform. The Health Visitor Implementation Plan (2011) set out a plan to recruit increasing numbers of nurses and midwives to the profession to deliver an expanded and refocussed health visiting service. Exploring this policy change from the viewpoint of those new to health visiting offers a unique perspective into how a specific policy vision is translated into nursing practice. Methods: A descriptive qualitative study in which participants were enrolled on a one-year post-graduate health visiting course at a University in South West of England. Qualitative data were collected pre- and post-qualification. A total of 16 interviews and a focus group were conducted with nine participants between September 2012 and March 2013. Findings: Descriptive data were interpreted using Lipsky's theoretical framework of street-level bureaucracy. Three themes emerged which relate to this 'bottom-up' perspective on policy implementation; readiness to operationalise policy, challenges in delivering the service vision; and using discretion in delivering the vision. Community public health nurses operate as street-level bureaucrats in negotiating the demands of policy and practice, and by this means, attempt to reconcile professional values with institutional constraints. Barriers to policy implementation at a local level mediate the effects of policy reform, ultimately impacting upon outcomes for children and families.
\end{abstract}

Key words: community public health nursing; health visitor implementation plan; health visitors; Lipsky's theoretical framework; qualitative research; street-level bureaucracy

Received 14 November 2015; revised 26 April 2016; accepted 22 May 2016;

first published online 4 August 2016

\section{Introduction}

The Health Visitor Implementation Plan (Department of Health, 2011a) policy reform led to unprecedented investment in community public health nursing services in England. Public health nurses, known in England as health visitors,

Correspondence to: Dr Alison Hughes, Department of Nursing and Midwifery, University of the West of England, Glenside Campus, Bristol BS161DD. Email: Alison2.hughes@uwe.ac.uk provide preventative health services to pre-school children and their families (Department of Health, $2011 b$ ), with similar roles existing in other developed countries (Kuo et al., 2006; Mills et al., 2012; Clancy et al., 2013). This policy reform was designed to meet the challenges posed by successive high-profile reports, which highlighted the need for support in the early years to reduce health inequalities (Field, 2010; Marmot et al., 2010; Allen, 2011); health visitors were identified as having a major role to play in improving public health

\footnotetext{
(C) Cambridge University Press 2016
} 
outcomes for children (Allen, 2011). It was recognised that numbers of health visitors had fallen for a decade, leading to individual caseloads of over 500 pre-school children in some areas (Family and Parenting Institute, 2007). Concern was therefore raised that an equitable, high quality, well child service was not being delivered (Allen, 2011; Department of Health, 2011a). The Health Visitor Implementation Plan set out a new vision for community public health nurses, supported by dedicated funding to support the training and employment of new recruits to the profession.

The aim of the Health Visitor Implementation Plan was to offer all families a core programme of evidence-based preventative health care, plus targeted support for those with the greatest health needs (Department of Health, 2011a). The Chief Nurse for England commented

The new vision explains the kinds of services we all want to see available to families in every community. This vision is set out as a 'service offer to families'.

(Bennett, 2011: 42)

From 2009 to the present, health visitors have provided services at four levels within the Healthy Child Programme (Department of Health, 2009a) as part of a system of 'progressive universalism' (Hogg et al., 2013; Oberklaid et al., 2013), and the 'new vision' aimed to expand and strengthen these services. At level one, interventions are aimed at improving child health in the community; the second level is a core programme of contacts and reviews offered to all families; the third level provides an enhanced service for common problems (for instance with feeding or behaviour); and at the fourth level families with the highest health needs are offered intensive multidisciplinary support. A similar array of services exists in other countries but with wide differences in the range and intensity of services offered (Kuo et al., 2006; Esso van et al., 2010). International debate about the optimum programme of child health promotion to offer to pre-school children and their families is the subject of international debate (Esso van et al., 2010; Oberklaid et al., 2013).

In order to provide the Healthy Child Programme (Department of Health, 2009a) at the appropriate level for each family, a target was set of 4200 additional specialist community public health nurses to be trained by 2015 , representing a $50 \%$ increase in number of full time practitioners. This major ideological and financial investment in health visiting, took place in a climate of austerity, when many other public services experienced budgetary cuts (Karanikolos et al., 2013). This investment is unusual both in the UK and abroad, as community nursing is rarely at the forefront of policy and tends to lose out in funding terms to hospital services. The aim of this study was to investigate the implementation of this new policy vision from the perspective of those entering health visiting and who were integral to this policy reform.

\section{Background}

Nursing policy is notoriously under researched and under analysed (Ham, 2004; Traynor, 2013), despite nurses being a large professional group who provide the majority of direct patient care (Baggott, 2010). In health visiting, major reform has occurred over the last 20 years, particularly in relation to number of universal contacts with pre-school children. The series of 'Hall reports' (Hall, 1989; 1991; 1996; Hall and Elliman, 2003) recommended reducing universal contacts, with the final report advocating no further routine health visitor contacts after four months of age. A combination of policy drivers subsequently led to a change of policy direction and the reinstatement of universal reviews at one and two years (Department of Health, 2009b). Commentators have questioned the way in which policy changes that impact upon public health nursing practice (such as the Hall reforms) are implemented without accompanying evaluation or monitoring of outcomes (Condon, 2008; 2011; Bellman and Vijeratnam, 2011). In the case of the Health Visitor Implementation Plan, Buttivant (2011) has pointed to a lack of evidence for this policy initiative, suggesting the plan could be a high-risk strategy if outcomes for children are not improved. It is important to analyse policy change within nursing in order to illuminate the policy processes linked to specific initiatives, and also to add to the body of literature exploring policy change within nursing.

Lipsky's (1980) street-level bureaucracy theory provides a theoretical framework to examine and analyse the mechanisms by which policy is translated into practice in many health and welfare 
contexts (Corrazzini, 2000; Vesneski, 2009; Ellis, 2011), and has previously been applied to nursing (Walker and Gilson, 2004; Bergen and While, 2005; Condon, 2008). Lipsky's theory, which was developed from studying the behaviour of frontline staff in public service agencies, challenges 'top down' models of policy creation which suggest policy is decided by politicians and delivered by administrators (Hudson and Lowe, 2004). In contrast, Lipsky (1980) perceives policy as ultimately being the service delivered to clients. This means public servants, as street-level bureaucrats, act as front-line mediators between policy makers and the recipients of services. Evans (2011) offers a critique of this 'bottom-up' theory of policy implementation to argue that Lipsky's view of the dichotomous relationship between professionals and managers - and the tension to which this gives rise - is overstated. However, in a progressively managerial and bureaucratic public service landscape this model is increasingly recognised as relevant to aspects of 21st century health service delivery, specifically the behaviour of health professionals in delivering care to clients (Cooper et al., 2015). Street-level bureaucrats commonly work within a situation of low support, in which resources are scarce and there are often ambiguous and unattainable expectations of performance (Hill, 1997). Scarcity of resources for community public health nursing (including a lack of funding, staffing and training) have been identified in Canada (Valaitis et al., 2014), the United States (Stanhope and Lancaster, 2013) and Ireland (Clarke, 2004).

Nurses are archetypal street-level bureaucrats as they frequently balance high demand for their services with limited supply, and negotiate institutional and bureaucratic requirements, whilst seeking to respond flexibly to the needs of individuals (Lipsky, 1980). The ethical dilemmas of balancing public health needs, with those of individuals, and practising according to professional judgement whilst respecting client autonomy have been identified in community public health nursing (Cowley and Frost, 2006; Greenway et al., 2013). It has been argued that the 'flip-side' of prioritisation is rationing (Klein et al., 1996), and that nurses are involved in rationing health services in their work. This aspect of nursing is rarely considered (Wilmot, 2003), but Hogg et al. (2013) have begun the debate in relation to health visiting. Core frameworks such as the Healthy Child Programme (Department of Health, 2009a) potentially contribute to greater rationing as well as targeting of services (Baggott, 2004; Checkland', 2004), challenging nurses' professional and institutional values. Using Lipsky's theory, this paper examines how the new vision for health visiting has been implemented in practice by student and novice community public health nurses, adding to theoretical understanding of policy change in nursing.

\section{The study}

\section{Aim}

The aim of the research was to explore the experiences of student and novice community public health nurses in implementing health visiting policy reform pre- and post-qualification. The views of students were seen as important, as those entering the profession were a key part of the new policy reform.

\section{Design}

A qualitative descriptive methodology was employed. This draws on the broad principles of naturalistic inquiry, and describes and summarises events and experiences in terms and language used by those taking part in the study (Sandelowski, 2000). The qualitative methods used (semi-structured interviews and focus group) are in keeping with the exploratory nature of the study (Barbour, 2008). A longitudinal approach enabled an exploration of students' experiences over time and allowed early trends in data to be followed (Murphy-Black, 2000).

\section{Participants}

Sampling was purposive, a commonly used strategy in qualitative methodology (Fielding and Thomas, 2008). One cohort of 18 students who were based in practice across the South West of England were verbally invited to participate by the Principal Investigator (A.H.) and given written information. Those willing to participate were asked to return their contact details. Initially, ten students agreed to participate (55\%); one student subsequently withdrew before data collection due to sickness. Initial interviews were therefore held with nine participants, eight of whom then participated in a focus group. Final interviews were 
Table 1 Description of sample and participation in data collection

\begin{tabular}{|c|c|c|c|c|c|}
\hline $\begin{array}{l}\text { Participant } \\
\text { pseudonym }\end{array}$ & Interview 1 & Focus group & Interview 2 & $\begin{array}{l}\text { Community } \\
\text { experience? }\end{array}$ & $\begin{array}{l}\text { Existing } \\
\text { qualification(s) }\end{array}$ \\
\hline $\begin{array}{l}\text { Eva } \\
\text { Harriet } \\
\text { Ayesha } \\
\text { Nicola } \\
\text { Sue } \\
\text { Andrea } \\
\text { Fiona } \\
\text { Gill } \\
\text { Jane }\end{array}$ & $\begin{array}{l}\sqrt{ } \\
\sqrt{ } \\
\sqrt{ } \\
\sqrt{ } \\
\sqrt{ } \\
\sqrt{ } \\
\sqrt{ }\end{array}$ & $\begin{array}{l}\sqrt{ } \\
\sqrt{ } \\
\sqrt{ } \\
\sqrt{ } \\
\sqrt{ } \\
\sqrt[V]{ } \\
\sqrt[V]{ }\end{array}$ & $\begin{array}{l}\sqrt{ } \\
\sqrt[V]{ } \\
\sqrt{V} \\
\sqrt[V]{ } \\
\sqrt[V]{ }\end{array}$ & $\begin{array}{l}x \\
x \\
\sqrt{ } \\
x \\
x \\
\sqrt{ } \\
x \\
x \\
x\end{array}$ & $\begin{array}{c}\text { Midwife } \\
\text { Midwife } \\
\text { Nurse } \\
\text { Midwife } \\
\text { Midwife } \\
\text { Midwife } \\
\text { Midwife } \\
\text { Nurse } \\
\text { Nurse and Midwife }\end{array}$ \\
\hline
\end{tabular}

held with seven of the original sample; two declined, one having left health visiting. Table 1 provides details of participants.

\section{Data collection}

In total, 16 individual interviews and one focus group interview were conducted with nine participants over a ten-month period between September 2012 and March 2013. Semi-structured individual interviews allowed for in-depth exploration of participants' experiences (Fielding and Thomas, 2008). Using a focus group enabled students to clarify, challenge and extend data arising from individual interviews (Bloor et al., 2001; Gill et al., 2008).

Data were collected at three points in the student journey. Interviews were held face to face when students attended university, or conducted by telephone where students preferred. Individual interviews were held eight months into the oneyear specialist public health nursing (SCPHN) programme (September 2012) and a focus group interview took place at the university six weeks later, when students were working more autonomously, although not yet qualified (November 2012). Final interviews were held when participants had been qualified for three months (March 2013) (see Table 1). Interviews lasted between 30 and $60 \mathrm{~min}$, and the focus group $90 \mathrm{~min}$. All data were collected by the Principal Investigator (A.H.).

Data collection was iterative. The first set of interviews provided data on students' understanding of the new service vision and its implementation in practice. The focus group built on this data to further explore some of the obstacles and opportunities regarding policy implementation. In the final interviews, and in response to student suggestions, the focus was on autonomous practice and whether expectations regarding health visiting had materialised (see Table 2).

\section{Ethical considerations}

A favourable ethical opinion was given by a University Ethics Committee. Participants were advised that the Principal Investigator (A.H.), although a member of academic staff was not a health visitor or part of the SCPHN academic team. All data has been anonymised and pseudonyms have been used throughout (British Sociological Association, 2002). Focus group participants were given a gift token as a 'thank you'.

\section{Data analysis}

Data analysis was on-going during the period of data collection. Data were recorded and transcribed verbatim and all data subjected to the same process of inductive thematic analysis, a commonly used technique in qualitative research (Braun and Clarke, 2006; Sandelowski, 2010). Transcripts were read line-by-line by A.H. and L.C., and key words and phrases manually noted and coded. Descriptive categories were developed from these codes and subsequently collapsed into broader themes (Coffey and Atkinson, 1996). The themes were then reviewed, agreed by both authors and defined to ensure they encompassed and reflected the coded data. Lipsky's street-level bureaucracy theory (1980) was used as a policy analysis 
Table 2 Summarised version of the topic guide for individual interviews and focus group interview

\begin{tabular}{|c|c|c|}
\hline $\begin{array}{l}\text { Topic guide for first interviews } \\
\text { [4 months before qualifying as a } \\
\text { health visitor (September 2012)] }\end{array}$ & $\begin{array}{l}\text { Topic guide focus group } \\
\text { [1 month before qualifying as a } \\
\text { health visitor (November 2012)] }\end{array}$ & $\begin{array}{l}\text { Topic guide second interviews } \\
\text { [3 months post-qualification } \\
\text { (March 2013)] }\end{array}$ \\
\hline $\begin{array}{l}\text { What does the new health visiting } \\
\text { service vision mean to you? }\end{array}$ & $\begin{array}{l}\text { What are the key skills and } \\
\text { knowledge you need to meet } \\
\text { current service demands and } \\
\text { the service vision? }\end{array}$ & $\begin{array}{l}\text { Tell me what the last } 3-4 \text { months have } \\
\text { been like for you since becoming a } \\
\text { qualified health visitor? }\end{array}$ \\
\hline $\begin{array}{l}\text { To what extent has your view } \\
\text { changed during training? }\end{array}$ & $\begin{array}{l}\text { How have you sought to address } \\
\text { the public health agenda in } \\
\text { your work with families? }\end{array}$ & $\begin{array}{l}\text { To what extent have you been able to } \\
\text { practice in the way you wanted/hoped } \\
\text { you would be able to? }\end{array}$ \\
\hline $\begin{array}{l}\text { In terms of what you are seeing in } \\
\text { practice, what appear to be the } \\
\text { current health visiting service priorities? }\end{array}$ & $\begin{array}{l}\text { What do you see as the } \\
\text { opportunities and barriers to } \\
\text { delivering the service vision? }\end{array}$ & $\begin{array}{l}\text { To what extent have you been able to } \\
\text { practice autonomously? }\end{array}$ \\
\hline How are you responding to those? & $\begin{array}{l}\text { When I interview you post- } \\
\text { qualification, what should I } \\
\text { ask? }\end{array}$ & $\begin{array}{l}\text { Is being a qualified health visitor what you } \\
\text { expected? }\end{array}$ \\
\hline $\begin{array}{l}\text { If you were asking these questions, is } \\
\text { there anything you would want to know } \\
\text { that I haven't asked? }\end{array}$ & & $\begin{array}{l}\text { Did you make the right decision, leaving } \\
\text { your old job? }\end{array}$ \\
\hline
\end{tabular}

framework to interpret findings, providing a lens through which to view participant experience.

\section{Rigour}

Consistent with qualitative inquiry, a number of strategies were used to aid rigour. During the different stages of data collection and analysis, copies of interview transcripts and emerging findings were discussed by the authors to aid trustworthiness (Guba and Lincoln, 1994). Credibility and authenticity was enhanced during data collection as students reflected on and developed emerging ideas and findings (Neergaard et al., 2009). Descriptive and interpretive validity (Sandelowski, 2000) was sought by inviting participants to comment on a draft of the study (Torrance, 2012). Just one participant did so, indicating the report reflected her experiences.

\section{Findings}

This paper reports on participants' experiences and understanding in relation to the new service vision for health visiting and its implementation in practice. To ground study findings in policy implementation theory, descriptive data have been interpreted and presented drawing on Lipsky's (1980) theoretical framework of street-level bureaucracy. Following in depth analysis of the data as described above, and discussion between the authors, three themes emerged across the data sets which relate to policy implementation and key

Primary Health Care Research \& Development 2016; 17: 586-598 street-level bureaucracy concepts. These themes reflect the 'bottom-up' perspective of Lipsky's street-level bureaucracy theory, illuminating and interpreting the processes by which nurses translate policy into practice. These were

- readiness to operationalise policy

- challenges to deliver the service vision

- using discretion in delivering the vision.

\section{Readiness to operationalise policy}

Operationalising policy refers here to the willingness of practitioners to put this national policy vision into practice. Students were supportive of the policy ambition for a renewed focus on public health and envisaged having more time with clients to engage in meaningful public health work. This theme emerged most strongly in initial interviews.

From the start of their training, participants saw themselves as having a responsibility for translating the new vision for health visiting into day-to-day work. Students described themselves as being a 'new breed' of health visitor entering the workforce, and thus an embodiment of national policy change. Rather than reform of the service necessarily being a shared role for the entire health visiting workforce, some students felt they were perceived as the practitioners who would 'deliver' changes in practice:

They are looking to us to rejuvenate the whole thing really. We are often told we are the future 
of the HV service ... to be creative, innovative and imaginative.

$$
\text { (Andrea, Interview 1) }
$$

We are told, you are one of the young ones... you are going to make all the changes ... you're going to lead this programme and you're going to change everything and make it better.

(Nicola, Interview 1)

Whilst some qualified health visitors were described as being positive and pro-active about service reform, others were disengaged from the exigencies of national policy. Several students speculated this was a result of the existing workforce having become exhausted and disillusioned due to a prolonged period of change and exceptionally high caseloads; this was particularly noticeable in those approaching retirement.

The majority of interviewees described investment in health visiting and the subsequent promise of being able to provide a high-quality service for children and families as being a major factor in their decision to retrain as a health visitor. Six students had opted for a career change because they were disillusioned with their current job, which they felt did not allow them to provide a high-quality service:

I'd become an administrator ... I felt I couldn't provide the service I wanted to.

(Sue, Interview 1)

Participants reported that pressure of work forced them into a task-orientated approach, which limited time for meaningful interaction with clients; thus they welcomed the possibilities of the Health Visitor Implementation Plan, which offered an inspiring new vision of an improved service for clients, accompanied by the opportunity for better resourced teams.

\section{Challenges to delivering the service vision}

Many participants considered that as students they were able to provide a good service to their clients, though they identified a number of issues which they felt had the potential to limit this service. Unlike their previous roles where they had been rushed and did not have time to devote to clients' needs, they felt able to develop and nurture relationships and respond proactively to concerns raised. This was seen as pivotal to good health visiting practice. However, many participants feared that once qualified this freedom would disappear, and trained staff sometimes reinforced this view:

I'm offering a fantastic service now, but I do worry that's because I am a student

(Nicole, Interview 1)

People say you can do extra visits now as a student, but you won't be able to do that when you are qualified.

(Focus Group participant)

Students perceived two challenges in implementing the vision for health visiting in practice. First, teams remained understaffed and high sickness rates led to difficulties in providing a full universal service. In some areas, health visitors were described as working to 'restricted practice' because there was insufficient capacity within the health visiting teams. 'Restricted practice' could be imposed at a management level, or decisions were made about which service to prioritise within each health visiting team. Targeted work had to be prioritised and thus the four levels of service delivery as laid out in the Health Visitor Implementation Plan could not be delivered to the extent envisaged in national policy:

Where I am working there is a very, very high caseload of Child Protection, so the emphasis is on child protection, and they are really, really struggling to deliver the Healthy Child Programme ....just when you are getting somewhere, you lose a member of staff through sickness, then you are back to square one.

(Jane, Interview 1)

We are meant to do an eight weeks post natal mental health check, but it isn't done - I think it's hard for us to see the benefits of the new service vision if it's not being offered.

(Harriet, Interview 1)

In situations where teams were struggling to deliver the Healthy Child Programme, undertaking additional work such as an enhanced 
service or public health work within the community, particularly community capacity building, was seen as an impossibility:

It's just getting by with the basic Healthy Child Programme at the minute. I think a lot of places in our Trust have been in crisis with low staffing levels ... trying to build capacity is something that is looked at as a nice idea in the background, but it isn't actually being put into action.

(Ayesha, Interview 1)

Students were concerned to prioritise their work in such a way as to minimise risks to clients. However, for some, this resulted in practising in a restricted and defensive way, with a focus on completion of notes:

It's more to do with accountability, wanting to ... make sure I have recorded it, than try to venture into other activities.

(Gill, Interview 1)

A second factor which influenced delivery of the Healthy Child Programme was the way in which health visiting services were commissioned locally. Local policy did not necessarily match what was presented within the Health Visitor Implementation Plan. For some students, the universal postnatal service was limited to one visit lasting one hour. Students perceived a pressure to complete a detailed health needs assessment within this time, which was the basis for decisions about who was offered a targeted service with further health visitor contacts. Many described this as a 'tick box' exercise which did not take into account the time required to forge relationships with families and establish trust:

Using a tick box [approach to assessment] what are you getting from that? Probably not a lot, but on paper it looks like you have, whereas if you are going in and exploring everything in much more depth, and do the assessment in partnership with them - it's a completely different approach.

(Nicole, Interview 1)

Some were reluctant to ask parents questions about domestic abuse or substance misuse at a first meeting, and considered that, without having had the opportunity to establish a relationship of trust, it was unlikely honest answers would be given. This 'tick box culture' paid only lip service to the wider ideals of the health visiting vision. One described learning to do an assessment within the required time as being a major part of her training from qualified staff:

... so they keep saying you need to learn to do that in an hour.

(Focus Group participant)

\section{Using discretion in delivering the vision}

In response to these and other challenges, participants used their discretion and professional judgement in implementing the new health visiting vision. First, students quickly found that parents were not passive recipients of services, but had ideas themselves about what they wanted, which did not necessarily match health visiting priorities. If practitioners could not offer credible solutions to common behavioural concerns, such as sleep problems or potty-training, they feared parents would become disillusioned with the service. Students thus described using their professional judgement to engineer a trade-off between meeting the agenda of parents, and meeting professionally identified (public health) goals:

Unless you do that, you can't work on the big stuff with families.

(Eva Interview 1)

If you don't have the answers to the common problems that people come to you with, it's like you've dropped the relationship through the floor.

(Focus Group participant)

Negotiating issues of service capacity and local commissioning arrangements, both of which influenced the level of service offered to clients, concerned students who perceived a dissonance between what they were being told to provide, and what they wished to provide to clients in line with their professional judgement and values:

So if you are on restricted practice and you are only allowed to do your one visit, do you just do one visit, or do you make that professional judgement that the person needs just another half-an-hour of your time on another day? (Focus Group participant) 
Participants often referred to what they were 'told' or 'allowed' to do, suggesting limits to their professional autonomy. One described the dilemma of having to meet health promotion and improvement targets, without having the autonomy to do this in a way she considered would meet these ends:

It's very difficult when commissioners are telling you, you have to hit these targets, and you can only do one visit.

(Focus Group participant)

Those who experienced greater autonomy related this to working with a supportive team and flexible management:

I've had that luxury of a relatively free diary to make those decisions and have been able to visit people as many times as I like, and I think definitely among the team, they are autonomous practitioners, everyone works differently. Providing we're meeting our targets and we're seeing everybody, I think our manager is happy for us ... to make those decisions ourselves.

(Eva, Interview 2)

Once qualified, most participants continued to experience time pressures, but generally found they could offer an extra visit to families if this was required. However, some practitioners 'bent the rules', by concealing the real purpose of visits, ascribing them instead to an activity considered acceptable to managers or local commissioners. Thus practitioners worked out how to offer more to clients within the organisational system:

You do feel like you want to do more, and you just have to justify it in some way. You have to actually write in the notes ... I don't know, 'breastfeeding support' or 'very anxious'.

(Harriet, Interview 2)

I think I do feel restricted ... I mean I would love to go and see the people I feel are more vulnerable ... you need that reason to go back ... it can't just be 'Oh, because I think they're vulnerable'. ... And sometimes you just can't identify anything extra, you just have that feeling.

(Ayesha, Interview 2)
Participants spoke of picking up 'subtle cues' about hidden health needs within families, but these were not judged adequate to justify an extra visit beyond the universal programme. Thus some participants described conflict between their professional opinion and the institutional and bureaucratic structures within which they worked:

If you can't slot it into a box, then there doesn't seem to be any scope for you to use your initiative.

(Ayesha, Interview 2)

\section{Discussion}

These findings are of significance to practitioners, analysts of health visiting and to policy makers who consider how nurses deliver policy in practice. This study raises a number of important questions regarding the implementation (and translation) of policy in practice, and the impact of resources on the ability of these newly qualified community public health nurses to deliver government policy. The data also contributes to the debate regarding the socialisation of students and the fate of student ideals and values (Maben et al., 2007).

Many students were keen to become community public health nurses because they saw greater opportunities to promote public health and to form therapeutic and meaningful relationships with service users - opportunities lacking in their previous jobs. Participants spoke with passion and conviction about their new role, and were enthusiastic exponents of the new policy vision. However, the impact of limited resources and organisational constraints influenced the level and scope of service provision offered, and required health visitors to manage their expectations. Understaffing, heavy workload, commissioning arrangements and the demands of child protection, meant the service offered was at times more reactive than pro-active and undermined efforts to deliver a service (and the vision) as they wished. This gap between positive intentions and the reality of practice has been well documented in previous studies of both nursing and health visiting (Kendall, 1993; Mitcheson and Cowley, 2003; Maben et al., 2007; Cowley et al., 2009; 2013). The obstacles to delivering the public health agenda identified by health visitors in this study, have also been detailed elsewhere (Rowe and

Primary Health Care Research \& Development 2016; 17: 586-598 
Carey, 2004; Machin et al., 2011). In Cameron and Christie's study (2007) for example, health visitors described a lack of resources, workload pressures and competing priorities as limiting factors in engagement with public health work.

This study suggests that community public health nurses modify policy to meet the needs of clients. Within Lipsky's theory (1980) it is recognised that public service workers inevitably struggle to meet the demands of clients, because such demands are inexhaustible. Based on the study findings, there are several ways in which street-level bureaucracy theory can contribute to an understanding of health visiting practice. First, students felt it necessary to 'step outside' the service offer and respond directly to the priorities of clients. Lipsky (1980) points out that those who work at 'the sharp end' of service delivery have considerable jurisdiction over how they manage their work, but that this power is rarely recognised by legislators and policy makers. Participants saw responding to the priorities of clients as necessary to cement the relationship, and had to take place before any preventive work could be done to improve health outcomes for the child. De la Cuesta $(1993 ; 1994)$ names this 'fringe work' which serves to establish a relationship with the family and pave the way for introducing the health visitor's therapeutic public health agenda.

Second, formal assessment of health needs was identified by participants as an important point at which their professional judgement and autonomy was constrained by what they saw as externally imposed rules and cultural norms. When assessing level of need, public servants (as street-level bureaucrats) are required to make decisions about allocation of time and resources, leading to potential conflict with professional values (Brandon, 2005). Participants expressed unease undertaking a health needs assessment which they felt compromised their ability to build relationships and provide appropriate care and support. Several studies argue that undertaking health needs assessment using an overly structured 'tick box' approach, undermines the development of partnership working and holistic, client centred care (Cowley and Houston, 2003; Appleton and Cowley, 2004; Greenway et al., 2013). Importantly, these relational aspects of practice are seen as key to public health work to redress health inequalities. In line with Condon's (2008) study, participants perceived local commissioning arrangements as prescriptive and target driven. Students talked about competing demands in terms of what they had been commissioned to provide as a health visiting service, versus the perceived needs of families.

In response, students found themselves negotiating competing demands, and in doing so, acted as street-level bureaucrats. Students used their discretion - interpreting and bending the 'rules' (eg, fabricating reasons for further input) in order to achieve their preferred ends and serve the needs of clients (Rowe, 2012). This undermined the implementation of wider policy at local level (delivering the Healthy Child Programme according to an established hierarchy of need), though arguably reinforced the wider policy intent (to support those in need). As street-level bureaucrats, students perhaps then occupied a dual role of 'agent of the state' and 'agent of the citizen', using their judgement to 'help their clients in circumstances that on paper might not have warranted it' (Rowe, 2012: 14). Once qualified, participants continued to grapple with providing a health visiting service which met clients' needs. Conflicting priorities and tensions in allocating time and services were apparent in this study, challenging Evans' (2011) view that Lipsky's theory overstated the duality between managers and professionals.

Whilst nurses and nursing's invisibility within the policy-making arena has consistently been identified (Rafferty, 1992; Davies, 1995; Antrobus and Brown, 1997; Hughes, 2010), using Lipsky's theory as an interpretive framework this study has highlighted nurses' role and influence as part of a different 'policy making' dynamic. Participants' accounts suggest this dynamic is no less problematic or challenging for nurses, as they mediate often conflicting demands and the (negative) impact of policy to ensure the needs of service users are met. A picture emerges of a policy in flux; resistance and cooperation co-exist, and what the policy 'looks like' at any one moment, is dependent on the operation of practitioners as street-level bureaucrats, as they negotiate and mediate policy and organisational demands with their professional values and the needs of clients. In her re-examination of street-level bureaucracy, Ellis (2011) suggests the operation of these forces in any policy field, can only be determined though 
empirical enquiry - this study has sought to present these forces at work in the delivery of the Health Visitor Implementation Plan.

\section{Limitations}

This was a small-scale study and examined a policy initiative limited to England. Whilst small, the sample was in line with qualitative research where exploration of the research problem is sought through in-depth continuing inquiry (Crouch and McKenzie, 2006). Data collection took place in 2012-2013, so the situation in practice may have improved by 2015 due to greater number of health visitors being trained and pressures on the workforce relieved [by March 2015 nearly 4000 more health visitors were in post (Health and Social Care Information Centre, 2015)]. Only the experiences of students were sought, so their perceptions in relation to the views of the qualified workforce (such as students being expected to lead policy reform) may not have been substantiated had qualified staff also been interviewed. In addition, participants were a self-selecting sample, $55 \%$ of one university cohort.

Participants may have been inhibited by the Principal Investigator being an academic member of staff, although she was not a health visitor or connected with the SCPHN programme. However, the analytical and often critical nature of their comments, suggests this did not invalidate the veracity of the data. Whilst telephone interviews were mainly held for convenience (several participants lived a great distance from the university), this method of data collection proved fruitful and generated a comparable amount and depth of data as face to face interviews (see also Sweet, 2002; Stephens, 2007).

\section{Conclusion}

In this study of policy implementation, an inadequately explored and under-theorised area of nurse practice is exposed to scrutiny by means of empirical enquiry. The study adds to the nursing application of street-level bureaucracy theory, by highlighting unresolved debates in nursing which are ignored at a policy level, and insufficiently explored within the profession and by policy makers. Such debates include the conflict between professional and institutional values, a disconnect between local commissioning and national policy, and nurses' roles in rationing the services they provide. These debates are of importance to all nurses, and further empirical study is required to explore the impact of national policies on grassroots nursing practice.

\section{Acknowledgements}

The authors would like to thank the participants for their time and thoughts and for the support of the SCPHN team at the University of the West of England. Thanks also go to the anonymous reviewers for their very helpful comments and suggestions.

\section{Financial Support}

This study was funded by the University of the West of England as part of the SPUR Early Career Researcher funding stream.

\section{References}

Allen, G. 2011: Early intervention: the next steps. An independent report to her majesty's government. London: The Stationary Office.

Antrobus, S. and Brown, S. 1997: The impact of the commissioning agenda upon nursing practice: a proactive approach to influencing health policy. Journal of Advanced Nursing 25, 309-15.

Appleton, J. and Cowley, S. 2004: The guideline contradiction: health visitors' use of formal guidelines for identifying and assessing families in need. International Journal of Nursing Studies 41, 785-97.

Baggott, R. 2004: Health and healthcare in Britain, third edition. Basingstoke: Palgrave.

Baggott, R. 2010: Public health: policy and politics. Basingstoke: Palgrave Macmillan.

Barbour, R. 2008: Introducing qualitative research. London: Sage.

Bellman, M. and Vijeratnam, S. 2011: From child health surveillance to child health promotion, and onwards: a tale of babies and bathwater. Archives of Disease in Childhood, doi:10.1136/adc.2010.186668.

Bennett, V. 2011: New vision for the profession. Community Practitioner 84, 42-3.

Bergen, A. and While, A. 2005: Implementation deficit and street-level bureaucracy: policy, practice and change in the development of community nursing issues. Health and Social Care in the Community 13, 1-10. 
Bloor, M., Frankland, J., Thomas, M. and Robson, K. 2001: Focus groups in social research. London: Sage Publications.

Brandon, T. 2005: Classic review. Disability \& Society 20, 779-83.

Braun, V. and Clarke, V. 2006: Using thematic analysis in psychology. Qualitative Research in Psychology 3, 77-101.

British Sociological Association 2002: Statement of ethical practice for the British Sociological Association. Retrieved 29 February 2016 from http://www.britsoc.co.uk/the-bsa/ equality/statement-of-ethical-practice.aspx.

Buttivant, H. 2011: The Health Visitor Improvement Plan 2011-2015. Retrieved 29 February 2016 from http:// ukpolicymatters.thelancet.com/policy-summary-the-healthvisitor-improvement-plan-2011-2015.

Cameron, S. and Christie, G. 2007: Exploring health visitors' perceptions of the public health nursing role. Primary Health Care Research and Development 8, 80-90.

Checkland, K. 2004: National service frameworks and UK general practitioners: street level bureaucrats at work? Sociology of Health and Illness 26, 951-75.

Clancy, A., Leahy-Warren, P., Day, M. and Mulcahy, H. 2013: Primary health care: comparing public health nursing models in Ireland and Norway. Nursing Research and Practice 2013, article ID 426107, doi: 10.1155/2013/426107.

Clarke, J. 2004: Public health nursing in Ireland: a critical overview. Public Health Nursing 21, 191-98.

Coffey, A. and Atkinson, P. 1996: Making sense of qualitative data. Thousand Oaks, CA: SAGE Publications.

Condon, L. 2008: Child health promotion in the United Kingdom: does health visitors' practice follow policy? Journal of Advanced Nursing 62, 551-61.

Condon, L. 2011: Do targeted child health promotion services meet the needs of the most disadvantaged? A qualitative study of the views of health visitors working in inner-city and urban areas in England. Journal of Advanced Nursing 67, 2209-219.

Cooper, M.J., Sornalingam, S. and O'Donnell, C. 2015: Street-level bureaucracy: an underused theoretical model for general practice? British Journal of General Practice 65, 376-77.

Corrazzini, K. 2000: Case management decision making: goal transformation through discretion and client interpretation. Home Health Care Services Quarterly 18, 81-96.

Cowley, S., Dowling, S. and Caan, W. 2009: Too little for early interventions? Examining the policy-practice gap in English health visiting services and organization. Primary Health Care Research and Development 10, 130-42.

Cowley, S. and Frost, M. 2006: The principles of health visiting: opening the door to public health practice in the 21st century. London: Community Practitioners' and Health Visitors Association.

Cowley, S. and Houston, A. 2003: A structured health needs assessment tool: acceptability and effectiveness for health visiting. Journal of Advanced Nursing 43, 82-92.

Cowley, S., Whittaker, K., Grigulis, A., Malone, M., Donetto, S., Wood, H., Morrow, E. and Maben, J. 2013: Why health visiting. A review of the literature about key health visitor interventions, processes and outcomes for children and

Primary Health Care Research \& Development 2016; 17: 586-598 families. Kings College, London: Department of Health Policy Research Programme.

Crouch, M. and McKenzie, H. 2006: The logic of small samples in interview-based qualitative research. Social Science Information 45, 483-99.

Davies, C. 1995: Gender and the professional predicament in nursing. Buckingham: Open University Press.

De la Cuesta, C. 1993: Fringe work: peripheral work in health visiting. Sociology of Health \& Illness 15, 665-82.

De la Cuesta, C. 1994: Relationships in health visiting: enabling and mediating. International Journal of Nursing Studies 31, 451-59.

Department of Health, 2009a: Healthy child programme: pregnancy and the first five years of life. London: Department of Health.

Department of Health. 2009b: Healthy child programme: the two year review. London: Department of Health. Retrieved 29 February 2016 from https://www.gov.uk/government/ uploads/system/uploads/attachment_data/file/377800/dh_ 108329.pdf.

Department of Health. 2011a: Health visitor implementation plan 2011-2015: a call to action. London: Department of Health. Retrieved 18 February 2016 from https://www.gov. uk/government/uploads/system/uploads/attachment_data/ file/213110/Health-visitor-implementation-plan.pdf.

Department of Health. 2011b: Educating health visitors for a transformed service. London: Department of Health.

Ellis, K. 2011: Street level bureaucracy revisited: the changing face of frontline discretion in adult social care in England. Social Policy and Administration 45, 221-44.

Esso van, D., del Torso, S. and Hadjipanayis, A. 2010: Paediatric primary care in Europe: variation between countries. Archives of Disease in Childhood 95, 791-95.

Evans, T. 2011: Professionals, managers and discretion: critiquing street-level bureaucracy. British Journal of Social Work 41, 368-86.

Field, F. 2010: The foundation years: preventing poor children becoming poor adults. London: HM Government.

Fielding, N. and Thomas, H. 2008: Qualitative interviewing. In Gilbert, G., editor, Researching social life, third edition. London: Sage, 123-44.

Family and Parenting Institute. 2007: Health visitors - an endangered species. London: Family and Parenting Institute.

Gill, P., Stewart, K., Treasure, E. and Chadwick, B. 2008: Methods of data collection in qualitative research: interviews and focus groups. British Dental Journal 204, 291-95.

Greenway, J., Entwistle, V. and ter Meulen, R. 2013: Ethical tensions associated with the promotion of public health policy in health visiting: a qualitative investigation of health visitors' views. Primary Health Care Research and Development 14, 200-11.

Guba, E. and Lincoln, Y. 1994: Competing paradigms in qualitative research. In Denzin, N. and Lincoln, Y., editors, Handbook of qualitative research. Thousand Oaks, CA: Sage Publications. 
Hall, D. 1989: Health for all children: a programme for child health surveillance/report of the joint working party on child health surveillance. Oxford: Oxford University Press.

Hall, D. 1991: Health for all children: a programme for child health surveillance/ report of a joint working party for child health surveillance, second edition. Oxford: Oxford University Press.

Hall, D. 1996: Health for all Children, third edition. Oxford: Oxford University Press.

Hall, D. and Elliman, D. 2003: Health for all children, fourth edition. Oxford: Oxford University Press.

Ham, C. 2004: Health policy in Britain: the politics and organisation of the national health service, fifth edition. Basingstoke: Palgrave MacMillan.

Hill, M. 1997: Understanding social policy. Oxford: Blackwell.

Hogg, R., Kennedy, C., Gray, C. and Hanley, J. 2013: Supporting the case for 'progressive universalism' in health visiting: Scottish mothers and health visitors' perspectives on targeting and rationing health visiting services, with a focus on the Lothian child concern model. Journal of Clinical Nursing 22, 240-50.

Health and Social Care Information Centre. 2015: NHS Workforce Statistics - March 2015. Health and Social Care Information Centre. Retrieved 19 February 2016 from http://www.hscic.gov. $\mathrm{uk} /$ searchcatalogue ? productid $=18106 \&$ topics $=2 \% 2 \mathrm{fW}$ ork force $\% 2 \mathrm{fStaff}+$ numbers $\% 2 \mathrm{fHospital+and+community+}$ health+service + staff $\&$ sort $=$ Relevance $\&$ size $=10 \&$ page $=1$ \#top.

Hudson, J. and Lowe, S. 2004: Understanding the policy process: analysing welfare policy and practice. Bristol: The Policy Press.

Hughes, A. 2010: The challenge of contributing to policy making in primary care: the gendered experiences and strategies of nurses. Sociology of Health \& Illness 32, 977-92.

Karanikolos, M., Mladovsky, P., Cylus, J., Thomson, S., Basu, S., Stuckler, D., Mackenbach, J. and McKee, M. 2013: Financial crisis, austerity, and health in Europe. The Lancet 381, 1323-331.

Kendall, S. 1993: Do health visitors promote client participation? An analysis of the health visitor-client interaction. Journal of Clinical Nursing 2, 103-9.

Klein, R., Day, P. and Redmayne, S. 1996: Managing scarcity: priority-setting and rationing in the national health service. Chicago, IL: Open University Press.

Kuo, A., Inkelas, M., Lotstein, D., Samson, K., Schor, E. and Halfon, N. 2006: Rethinking well-child care in the United States: an international comparison. Pediatrics 118, 1692-702.

Lipsky, M. 1980: Street level bureaucracy: dilemmas of the individual in public services. New York: Russell Sage Foundation.

Maben, J., Latter, S. and Macleod Clark, J. 2007: The sustainability of ideals, values and the nursing mandate: evidence from a longitudinal qualitative study. Nursing Inquiry 14, 99-113.

Machin, A., Machin, T. and Pearson, P. 2011: Maintaining equilibrium in professional role identity: a grounded theory study of health visitors perceptions of their changing professional practice context. Journal of Advanced Nursing $68,1526-537$.

Marmot, M., Allen, J., Goldblatt, P., Boyce, T., McNeish, D., Grady, M. and Geddes, I. 2010: Fair society, healthy lives: strategic review of health inequalities in England post 2010. London: UCL Institute of Health Equity.

Mills, L., Wong, S., Bhagat, R., Quail, D., Triolet, K. and Weber, T. 2012: Developing and sustaining leadership in public health nursing: findings from one British Columbia health authority. Nursing Leadership Toronto, Ontario 25, 63-75.

Mitcheson, J. and Cowley, S. 2003: Empowerment or control? An analysis of the extent to which client participation is enable during health visitor/client interactions using a structured health needs assessment tool. International Journal of Nursing Studies 40, 413-26.

Murphy-Black, T. 2000: Longitudinal research. In Cormack, D., editor, The research process in nursing, fourth edition. Oxford: Blackwell.

Neergaard, M., Olesen, F., Rikke, S., Andersen, R. and Sondergaard, J. 2009: Qualitative description - the poor cousin of health research? BMC Medical Research Methodology 9, 52 .

Oberklaid, F., Baird, G., Blair, M., Melhuish, E. and Hall, D. 2013: Children's health and development: approaches to early identification and intervention. Archives of Disease in Childhood 98, 1008-11.

Rafferty, A. 1992: Nursing policy and the nationalization of nursing: the representation of 'crisis' and the 'crisis' of representation. In Gray, A., Elkan, , R. and Robinson, J., editors, Policy issues in nursing. Buckingham: Open University Press.

Rowe, A. and Carey, L. 2004: The effect of population-based health needs assessment on health visitor practice. Primary Health Care Research and Development 5, 179-86.

Rowe, M. 2012: Going back to the street: revising Lipsky's street level bureaucracy. Teaching Public Administration 30, $10-18$.

Sandelowski, M. 2000: Whatever happened to qualitative description? Research in Nursing and Health 23, 334-40.

Sandelowski, M. 2010: What's in a name? Qualitative description revisited. Research in Nursing and Health 33, $77-84$.

Stanhope, M. and Lancaster, J. 2013: Public health nursingrevised reprint: population-centred health care in the community, eighth edition. London: Elsevier Health Sciences.

Stephens, N. 2007: Collecting data from elites and ultra elites: telephone and face-to-face interviews with macroeconomists. Qualitative Research 7, 203-16.

Sweet, L. 2002: Telephone interviewing: is it compatible with interpretive phenomenological research? Contemporary Nurse 12, 58-63.

Torrance, J. 2012: Triangulation, respondent validation, and democratic participation in mixed methods research. Journal of Mixed Methods Research 6, 111-23. 
Traynor, M. 2013: Nursing in context: policy, politics, profession. London: Palgrave Macmillan.

Valaitis, R., Schofield, R., Akhtar-Danesh, N., Baumann, A., Martin-Misener, R., Underwood, J. and Isaacs, S. 2014: Community health nurses' learning needs in relation to the Canadian community health nursing standards of practice: results from a Canadian survey. BMC Nursing 13,31 .
Vesneski, W. 2009: Street-level bureaucracy and family group decision making in the USA. Child \& Family Social Work 14, 1-5.

Walker, L. and Gilson, L. 2004: 'We are bitter but we are satisfied': nurses as street-level bureaucrats in South Africa. Social Science \& Medicine 59, 1251-261.

Wilmot, S. 2003: Ethics, power and policy: the future of nursing in the NHS. Basingstoke: Palgrave. 